\title{
供給能力制約下での余裕在庫率による 多品目向け最適化在庫補充方式
}

$\begin{array}{lll}\text { (正 員) 光國 } & \text { 光七郎 } & \text { (日立製作所) } \\ \text { (非会員) 畐田 } & \text { 幸宏 } & \text { (日立製作所) } \\ \text { (正 員) 都島 } & \text { 功 } & \text { (日立製作所) 生 } \\ \text { (正 員) 薦田 } & \text { 憲久 } & \text { (大阪大学) }\end{array}$

Optimal Ordering Method under the Limited Capacity for Multi-Items by the Margin Stock Ratio

Koshichiro Mitsukuni, Member, Yukihiro Tomita, Non-member (Hitachi, Ltd.) Isao Tsushima, Member (Yokkaich University) Norihisa Komoda, Member (Osaka University)

The new re-order system aims to prevent running out of stock, to limit replenishment quantities and to keep reasonable stock level for multi-items. In the Lot-size re-order system and the Interval re-order system, replenishment intervals or quantities are determined by the each system after replenishment items are decided. When both re-order systems run for multi-items, total replenishment quantities usually over or under the limited capacity. The problem of the limited capacity was solved by the production scheduling or supply lead-time delay. We propose Optimal Ordering Method (OOM) to be controlled by the margin stock ratio under the limited capacity. Margin stock ratio is defined by the prediction of the out-of-stock situation that is calculated by the available stock of inventory and necessary demand quantities of supply lead-time period. After each item is arranged by the margin stock ratio, replenishment items are determined under the limited capacity. This new method has been applied to a window frame manufacturing process successfully.

キーワード : 在庫管理, 在庫補充方式, 余裕在庫率, 供給能力制約

\section{1. はじめに}

多品目の製品を供給能力に制約がある生産プロセスで在 庫補充する場合、工程能力が超えないように補充要求する必 要がある。個別品目ごとの定量発注方式や定期発注方式(1)で は, 供給能力の制約を考慮していないため, この方式を多品 目向けの在庫補充に使用すると, 供給能力を超えた補充要求 により, 供給工程側の能力計画が立てにくかったり, 予定の 供給リードタイムどおりに入庫しなかったりする。

そこで, 供給能力の制約に対して, 補充要求元の在庫管理 では安全在庫量の個別品目への配分方法や在庫水淮の決め 方などで対応してきた (2)(3)(4)(5)。また, 供給先の工程側では工 程スケジューリングや供給リードタイムの遅延予測などで, 対応してきた。これらの方法の場合, 補充要求元と供給工程 側との間で実際の供給リードタイムより長いリードタイム を約束したり，予定の供給リードタイムより実際の供給リー ドタイムが長くなる場合に納入時期を回答したり, 実際に在 庫切れが発生した場合に緊急オーダを受付けて対応したり する。その結果, 多品目の在庫補充において, 補充要求元と 供給工程側との間で生産順序や納期の調整が多発する。この ように，供給側の工程能力を超えて多品目を補充する場合， 優先的に生産したい補充対象品目を決めることは難しい。

また, 各品目の在庫量が十分にあり，同時に発注点を割る 品目数が少なく, 補充要求総量が供給能力を下まわる場合が ある。この場合, 限られた供給能力を有効に活用するために,
発注点を割っていない品目を先行して生産することができ る。このような場合, 供給側は段取り替えや材料の準備など 生産のやりやすさやで, また, 需要側は売れ筋見通しなどで, 先行して生産する品目を決めようとする。の結果, 供給側 上需要側とで要望する品目が合わないことがあり, 補充要求 元と供給工程側との間で生産順序や納期の調整が多発する。 このように, 供給工程側に生産能力の余力が発生した場合に, 多品目の中から先行生産したい品目を決めることは難しい。 上記の問題を解決するため，本論文では，個別品目ごとの 在庫補充方式の忘用方法を改善するのではなく, 補充要求時 に多品目を想定して, 供給工程の操業能力の制約を補充総量 染で与え, 各品目の需要量の平均, 有効在庫量, 補充要求量, 供給リードタイムを用いて在庫切れの起こりやすさを計算 し, これを補充の順番として補充対象品目を決める, 最適化 在庫補充方式を提案する(6)(7)。各品目の供給リードタイム期 間内の需要量に対する有効在庫量の比を余裕在庫率と定義 し，余裕在庫率が小さい順に並べ替え，操業能力の制約を補 充総量枠としてその範囲内の品目を補充対象品目とする。ま た, 在庫量が必要以上に增えないよう上限余裕在庫率を決め, 各品目の余裕在庫率が上限余裕在庫率を超える場合は補充 を抑止する。これにより，操業能力の制約下で在庫切れ率を 低減し，かつ，在庫絰量の増加を抑止する。本論文では，供 給工程側のスケジューリング方式と在庫補充方式を分け，在 庫補充方式について考察する。 
以下, 第 2 章で最適化在庫補充方式のモデルを, 第 3 章で 最適化在庫補充方式の考え方を, 第 4 章で最適化在庫補充方 式のアルゴリズムを, 第 5 章で在庫総量と在庫切れ率をシミ ユレーションにより評価し，第6 章で適用効果を述べる。

\section{2. 最適化在庫補充方式のモデル工程}

本論文で対象とするモデル工程の一例を図 1 に示す。加工 工程 WS は, 操業能力 $E m$ 個/日で, 段取り替えにより $m$ 種類の多品目が絽り返し生産できる。加工工程 WS の加工 能力は, ある品目を $j$ とすると, 1 回あたりの加工指示で $Q b$ (j)個/回のバッ千加工が可能で, その加工時間を $T b(j)$ 日, 段取り替え時間を $T c(j)$ 日とする。

倉庫 WH は加工工程 WS の下流側にあり, 加工が終了し た各品目が保管され, その有効在庫量 (手持在庫量亡補充要 求残の和）を $A B(j)$ 個とする。需要に対する出庫は倉庫 WH から行われる。また, 各品目の補充要求量を $Q s(j)$ 個/回之 すると, 補充要求は, 加工工程 WS の入り口に要求し, 加 I工程 WS は, 供給リードタイム Ls $(j)$ 日後に倉庫 WH に 入庫する。

各品目の補充要求量 $Q s(j)$ 個／回の決め方は, 在庫切れを 起こさないために, 需要量分布の平均より大きく, かつ, 在 庫削減のためにできるだけ小さい量を設定する。補充要求量 $Q s(j)$ 個／回が大きすぎる場合，1回に補充要求できる品目 数が少なくなり, 各品目の補充機会が少なくなる。逆の場合 は, 加工工程 WS の段取り替え回数が多くなる。また, 供給 リードタイム $L s(j)$ 日は, 補充要求量 $Q s(j)$ 個/回をバッ 于加工数 $Q b(j)$ 個ノ回で除した值にバッチ加工時間 $T b$ （j）日を乗じ，段取り替え時間 $T c(j)$ 日を加えたもので, 式 (1) で求める。

$$
L s(j)=\frac{Q s(j)}{Q b(j)} \cdot T b(j)+T c(j) \cdots \cdots \cdot(1)
$$

なお, 各品目の補充要求に対して, 必要な部品·材料が直 ちに準備できるものとする。また，1 日の需要量分布は平均 $Q d(j)$ 個 /日, 標準偏差 $\sigma(j)$ の正規分布で, 各品目の供給 リードタイム期間内の需要量 $F d(j)$ 個は 1 日の平均需要量 $Q d(j)$ 個/日と供給リードタイム Ls ( $j$ )日の積である。

\section{3. 最適化在庫補充方式の考え方}

最適化在庫補充方式の考え方を図 2 に示す。定量発注方式 で在庫補充した場合, 複数品目が同時に発注点を割り, 各品 目の補充要求量の総和が操業能力 $E m$ 個/日を超える場合 は, 操業能力 $E m$ 個 /日の範囲内で優先して生産する補充対 象品目を決める。これを優先補充と呼ぶ。あるいは, 各品目 の補充要求量の総和が操業能力 $E m$ 個／日を下まわる場合 は, 操業能力 $E m$ 個 $/$ 日の箸囲内で, 発注点を割つていない 残りの多品目の中から先行して生産する補充対象品目を決 める。これを先行補充と呼ぶ。

優先補充, 先行補充する品目は各品目の在庫切れの起こり やすさで決める。各品目の在庫切れの起こりやすさは余裕在 庫率 $R m(j)$ と呼び, 各品目の供給リードタイム期間内の需 要量 $F d(j)$ 個に対する有効在庫量 $A B(j)$ 個との比を用い

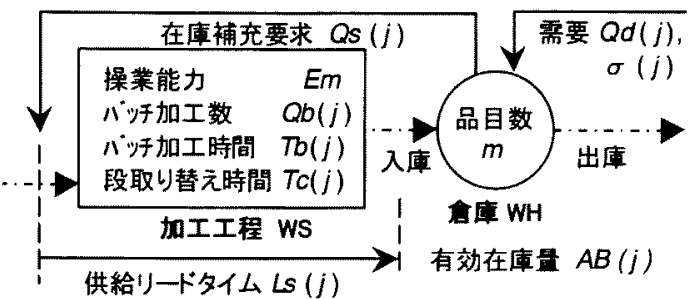

図 1 モデル工程

Fig. 1 Model Process

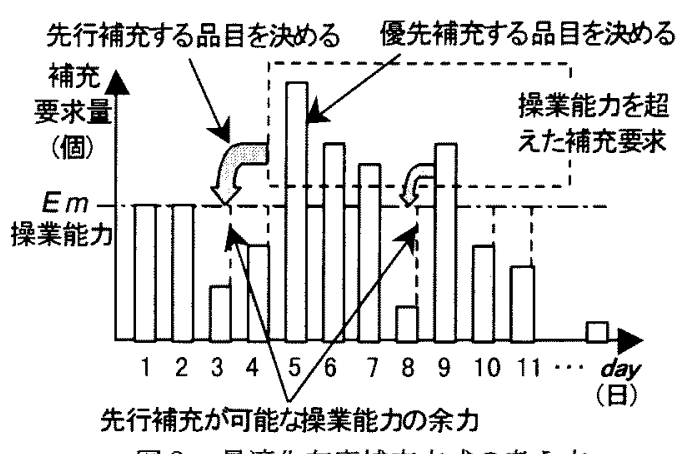

図2最適化在庫補充方式の考え方

Fig. 2 Concept of Optimal Ordering Method

て, 式（2）で定義する。

$$
R m(j)=\frac{A B(j)}{F d(j)} \cdots \cdots
$$

余裕在庫率 $R m(j)$ は, 有効在庫量 $A B(j)$ 個がゼロの場 合にゼロとなり在庫切れが発生していることを示し，有効在 庫量 $A B(j)$ 個が多いと大きな值となり在庫切れが起こりに くいことを示す。そこで, 補充対象品目 $j$ は, 図 3 で示すよ うに, 余裕在庫率 $R m(j)$ が小さい順に各品目を並べ替え, 式 (3) で示すように, 操業能力 $E m$ の範囲内で品目 $x^{*}$ を 決定し，j=1〜 $x^{*}+1$ までとする。なお, 並び順 $x^{*}+1$ の 品目で操業能力 $E m$ 個 /日を超えた部分は翌日の供給に繰り 越す。

$$
x^{*}=\left\{\max _{1 \leq x \leq m} x \mid \sum_{j=1}^{x} Q s(j)<E m\right\} \cdots
$$

また, 先行補充した場合の在庫総量は, 操業能力 $E m$ 個 日が各品目の平均需要量 $Q d(j)$ 個/日の総和より大きいの で、供給過剩で増え続ける。これを抑止するために, 各品目 の余裕在庫率 $R m(j)$ が指定の值を超えた場合は先行補充し ないようにする。この值を上限余裕在庫率 Prm と呼ぶ。上限 余裕在庫率 Prm は 1.0 以上の值で, この值が小さい場合, 有 効在庫量 $A B(j)$ 個の総和は少なくなり在庫切れ率が高くな る。逆の場合, 在庫切れ率は低くなるが, 有効在庫量の総和 は增加する。そこで, 上限余裕在庫率Prm は有効在庫総量 と在庫切れ率を制御するパラメータとして使用する。

4. 最適化在庫補充方式のアルゴリズム

最適化在庫補充方式のアルゴリズムを図 4 に示す。ここで, 
Step1 は, 各品目の余裕在庫率 $R m(j)$ を計算し, その一覧 表を作成する手続きで, 式（2）に基づいて計算する。表 1 に 余裕在庫率の計算例を示す。保有する品目数 $m$ は 10 品目 である。また, 各品目の供給リードタイムLs $(j)$ は, バッチ 加工数 $Q b(j)$ を 400 個/回, バッ于加工時間 $T b(j)$ を 5.0 日， 段取り替元時間 $T c(j)$ を 0.1 日に設定し, 式 (1) で計算し た值で, 補充要求量 $Q s(j)$ は平均需要量 $Q d(j)$ の 2 倍で設 定した值である。表中の $R m$ は計算結果の余裕在庫率である。

Step2 は, 各品目の発注点割れを調べる手続きで, 発注点 割れを起こしている品目に0, 起こしていない品目に1のフ ラグを付加して区分ける。

Step3 は発注点割れを起こしている品目グループと起こし ていないグループのそれぞれについて, 各品目の余裕在庫率 $R m(j)$ が小さい順に各品目を並べ替える手続きで, 表 2 は, 表 1 を並べ替えた例である。

Step4 は補充品目の決定手続きで, まず, 発注点割れを起 こしている品目グループについて式 (3)に基づいて操業能 力 $E m$ の籁囲内にある補充対象品目 $j=1 \sim x^{*+1}$ を決定する。 例えば, 表 2 で示すように, 操業能力 $E m$ が 1000 個/日の場 合, $x^{*}=4$ で, 補充対象品目は, HU08, HU07, HU06, HU03, $x^{*+1}$ の HU09 までの 5 品目である。なお, $x^{*+1}$ の品目によって当 日の補充総量が操業能力 $E m$ を超えた 80 個の部分は翌日の 生産に繰り越すので, 翌日の操業能力の制約 $E m$ はその分を 減ずる。

また, 発注点割れを起こした品目グループの補充要求量の 総和が操業能力 $E m$ より少ない場合, 先行補充する品目を発 注点割れを起こしていない品目グループから追加決定する。 先行補充対象品目は, 上限余裕在庫率 $P r m$ 以下の余裕在庫 率 $R m(j)$ で, かつ, 式 (3)に基づて操業能力 $E m$ の範囲 内の品目 $j=1 \sim x^{*+1}$ を決定する。

\section{5. シミュレーションによる在庫量と在庫切れ率の評洒}

\section{1 シミュレーションの目的とモテル}

提案方式の在庫総量と在庫切れ率について, 定量発注方式 と同一の需要条件, 補充条件を用いて, シミュレーションに より比較・評価する。シミュレーションに用いるモデル工程 は図 1 を用い, 需要条件と補充条件は表1を使用し, 需要デ 一夕は各品目ごとに平均需要量 $Q d(j)$ の 2 倍の值を最大值 とし, また, 最小値を 1 としてランダムに生成する。生成し た需要データの需要総量の分布例を図 5 に示す。また, 操業 能力 $E m$ は 1 日の平均需要量の総和である 1000 個とする。

定量発注方式のシミュレーションにおいて, 複数の品目が 同時に操業能力を超えた場合は, 同一品目に補充が偏らない ように補充品目をローテーションする。なお, 定量発注方式 の発注点は, 各品目の供給リードタイム期間内の需要量 $F d$ (j) と安全在庫量 $S(j)$ で決まるため, 式 (4)で求める(8)。

$$
\begin{aligned}
& I(j)=F d(j)+S(j) \cdots \\
& S(j)=k \cdot \sqrt{L s(j)} \cdot \sigma(j)
\end{aligned}
$$

ここで, $k$ は安全在庫俰数で, サービス率によりきまる定数

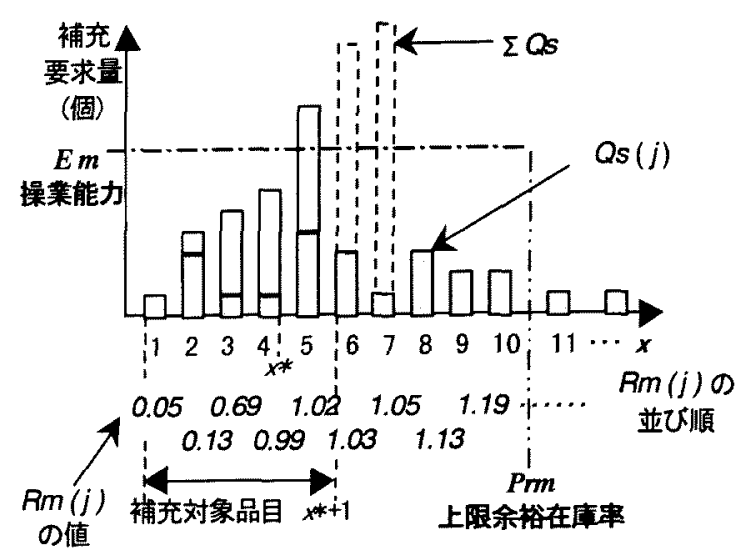

図 3 補充対象品目の決定方法

Fig. 3 Deternination of Replenishment Items

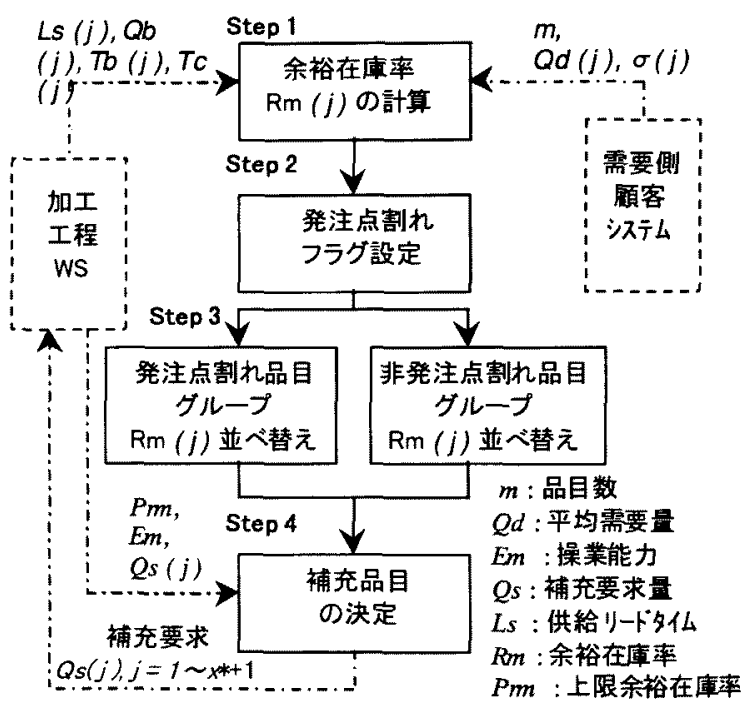

図 4 最適化在庫補充方式のアルゴリズム

Fig. 4 Algorithm of Optimal Ordering Method

表 1 余裕在庫率の計算例

Table 1 Calculation Sample of Margin Stock Ratio

\begin{tabular}{|lccccc|ccc|}
\hline 品目 & Od & $\sigma$ & Ls & Fd & S & AB & Rm & Flag \\
\hline HU01 & 60 & 32.1 & 2 & 120 & 89 & 214 & 1.7833 & 1 \\
HU02 & 70 & 41.4 & 2 & 140 & 115 & 140 & 1.0000 & 0 \\
HU03 & 80 & 46.6 & 3 & 240 & 158 & 101 & 0.4208 & 0 \\
HU04 & 90 & 52.3 & 3 & 270 & 178 & 487 & 1.8037 & 1 \\
HU05 & 100 & 56.5 & 3 & 300 & 192 & 439 & 1.4633 & 0 \\
HU06 & 100 & 59.6 & 3 & 300 & 202 & 124 & 0.4133 & 0 \\
HU07 & 110 & 61.8 & 4 & 440 & 242 & 149 & 0.3386 & 0 \\
HU08 & 120 & 70.9 & 4 & 480 & 278 & 8 & 0.0167 & 0 \\
HU09 & 130 & 77.3 & 4 & 520 & 303 & 242 & 0.4654 & 0 \\
HU10 & 140 & 79.3 & 4 & 560 & 311 & 306 & 0.5464 & 0 \\
\hline 合計 & 1000 & \multicolumn{10}{|c|}{3370} & 2068 & 2210 & & \\
\hline
\end{tabular}

であり，サービス率 90\%，95\%，97.5\%，99.5\%，99.9\%に対応 した安全在庫係数 $k=1.64,1.96,2.25,2.81,3.27$ の 例について, 在庫切れ率と在庫総量をシミュレーションする。 提案方式のシミュレーションは, サービス率 0\%, 90\%, 95\%, 
99.99に対応した安全在庫係数 $k=0.0 ， 1.64 ， 1.96,3.27$ の4例について，それぞれ，上限余裕在庫率 Prm を 1.0 か ら0.1づつ増分し 2.4 まで変化した場合の在庫切れ率と在庫 総量を評価する。

また, 各方式とも，在庫総量は，各品目ごとの有効在庫量 $A B(j)$ を測定し，その総和 $\Sigma A B$ を採用する。在庫切れ率は, 生成した各需要を出庫する際に手持在庫が不足して出庫で きなかった回数を測定し，各品目の需要総件数で除した割合 を採用する。また, 在庫切れの需要デー夕は入庫待ちにしな いで需要からキャンセルする。各品目の初期在庫量は供給リ 一ドタイム期間内の需要量 $F d(j)$ とする。1 回のシミュレ ーション期間は 240 日で, 評価は繰り返し 3 回のシミュレー ションで得た結果の平均を用いる。

\section{2 上限余裕在庫率のシミュレーション結果}

上限余裕在庫率を変化させた場合の在庫切れ率と在庫総 量を調べた。図6に上限余裕在庫率に対する在庫切れ率を示 す。横軸は上限余裕在庫率で, 縦軸は在庫切れ率である。在 庫切れ率は，上限余裕在庫率が小さくなるにつれて高くなり 逆の場合は低くなっている。また, 安全在庫係数が大きいと 発注点は高くなり，逆の場合は低くなるので, 余裕在庫率の 下限は発注点に合わせて一定化する。そのため, 余裕在庫率 より小さい上限余裕在庫率の場合は先行補充されなくなり， 在庫切れ率は安全在庫係数の水準で一定化する。一方で, 安 全在庫係数 $k=0$ とした場合, 在庫切㣗率は, 上限余裕在庫 率の変化に合わせて推移することがわかる。

次に，上限余裕在庫率に対する在庫総量を図 7 に示す。横 軸は上限余裕在庫率で, 縦軸は在庫総量である。安全在庫係 数を設定した場合, 在庫総量の下限は発注点に合わせて一定 化する。一方で, 安全在庫係数 $k=0$ とした場合, 在庫総量 は，上限余裕在庫率の変化に合わせて推移することがわかる。 これらのことから，提案方式で上限余裕在庫率を設定する ことは, 安全在庫係数を設定することと同様の働きを持ち, 先行補充によって安全在庫量相当を確保していると考える ことができる。このことから, 提案方式では, 安全在庫保数 $k$ をゼロに設定しても, 安全在庫係数に代わり, 上限余裕在 庫率 Prm を用いて在庫切れ率と在庫総量の制御が可能であ るといえる。

また, 在庫切れ率が $2.5 \%$ 以下で，かつ, 在庫総量が供給 リードタイム期間内の需要量の総和 $\Sigma F d の 2$ 倍以下となる ように在庫補充する場合, これらの図から, 上限余裕在庫率 Prm の值は, 1.5 2.0が適切であるといえる。

5.3 在庫切れ率と在庫総量のシミュレーション結果

提案方式と定量発注方式の在庫切れ率のシミュレーショ ン結果を図 8 に示す。絴軸は在庫切れ率, 横軸は安全在庫係 数である。操業能力の制約下において, 定量発注方式の在庫 切れ率は 19.6〜 13.3\%と高い。これに対して, 提案方式は在 庫切れ率が $2.5 \%$ 以下と低い。次に, 提案方式の在庫切れ率 の最大, 最小について調べた。図 9 に示すように, 在庫切れ 率は, 最大と最小のばらつきが少なく一定化し, 安全在庫係 数が大きくなると低減する。これらの図から，余裕在庫率に
表 2 補充対像品目の決定例

Table 2 Determination Sample of Replenishment Item

\begin{tabular}{|c|c|c|c|c|c|c|}
\hline \multicolumn{4}{|c|}{ 亚び } & \multicolumn{3}{|c|}{ 操業能力 $=1000$} \\
\hline 順序 & 品目 & Flag & $\mathbf{R m}$ & Qs & $\Sigma \mathrm{Qs}$ & 対象 \\
\hline 1 & HU08 & 0 & 0.0167 & 240 & 240 & * \\
\hline 2 & HU07 & 0 & 0.3386 & 220 & 460 & * \\
\hline 3 & HU06 & 0 & 0.4133 & 200 & 660 & * \\
\hline 4 & HU03 & 0 & 0.4208 & 160 & 820 & * \\
\hline 5 & HU09 & 0 & 0.4654 & 260 & 1080 & $x^{*}+1$ \\
\hline 6 & HU10 & 0 & 0.5464 & 280 & 1360 & \\
\hline 7 & HU02 & 0 & 1.0000 & 140 & 1500 & \\
\hline 8 & HU05 & 0 & 1.4633 & 200 & 1700 & \\
\hline 9 & HU01 & 1 & 1.7833 & 120 & 1820 & \\
\hline 10 & HU04 & 1 & 1.8037 & 180 & 2000 & \\
\hline
\end{tabular}

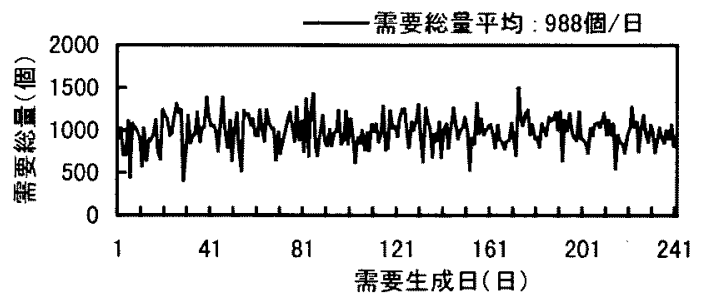

図 5 需要デー夕の生成例

Fig. 5 Generation Sample of Demand Data

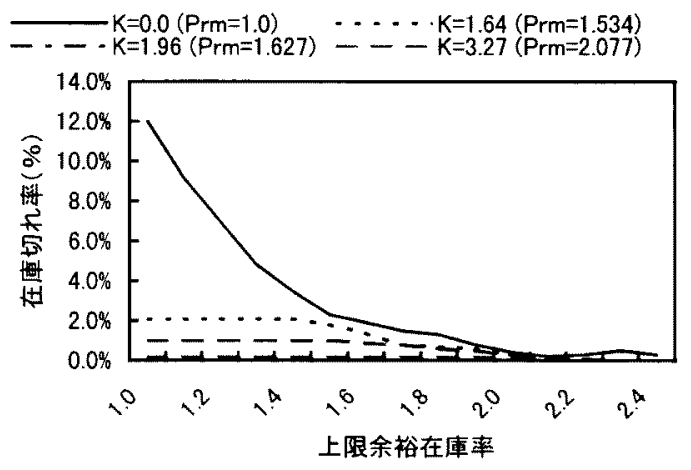

図 6 上限余裕在庫率上在庫切れ率シミュレーション結果 Fig. 6 Result of Out of Stock Ratio by Rm in OOM

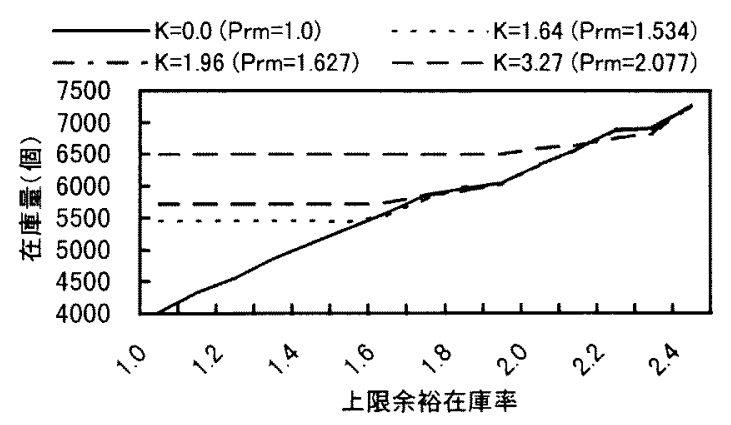

図 7 上限余裕在庫率と在庫総量のシミュレーション結果 Fig. 7 Result of Inventory by Rm in OOM 
よる優先補充と先行補充は在庫切れ率の低減と一定化に有 効であることがわかる。

次に, 定量発注方式と提案方式の在庫総量のシミュレーシ ヨン結果を図 10 に示す。提案方式は, 定量発注方式に比べ て在庫総量が $5 \sim 12 \%$ 少ない。また, 定量発注方式, 提案方 式，共に在庫総量は安全在庫係数にそって推移している。図 8 と図 10 から, 提案方式は操業能力の制約下において, 在 庫切れ率を低減し, かつ, 在庫総量を削減することに有効で あることがわかる。

\section{4 需要総量が変動した場合のシミュレーション結果}

需要総量が変動した場合の在庫切れ率と在庫総量につい て調ベた。図 11 は在庫切れ率のシミュレーション結果で, 縦軸は在庫切れ率, 横軸は需要総量である。需要総量が操業 能力を超えた場合は供給総量が不足するため, 定量発注方式 の在庫切れ率は 23.8 27.7\%と高い。同様に, 提案方式にお いても, 在庫切れ率が $6.4 \sim 12.3 \%$ と高いが, 定量発注方式 より著しく低い值で推移している。

次に, 在庫総量のシミュレーション結果を図 12 に示す。 縦軸は在庫総量, 横軸は需要総量である。定量発注方式の場 合, 在庫総量が增ている。その理由は, 在庫切れで需要がキ ヤンセルされた分の払い出しが減ったためと考えられる。ま た, 提案方式の場合, 優先補充により, 在庫切れが起こりや すい品目が先に補充されるため, 在庫切れによる注文キャン セルが少なく, 在庫総量は減少したと考えられる。図 11 と 図 12 から, 需要総量が変動した場合も, 提案方式は操業能 力の制約下において, 在庫切れ率を低減し, かつ, 在庫総量 を削減することに有効であることがわかる。以上のシミュレ 一ション結果から, 提案方式は, 供給能力の制約下で在庫切 れ率を低減し，かつ，在庫削隇に有効であるといえる。

\section{6. 適用事例}

アルミ製密枠を受注組立て生産方式で生産しているある メーカにおいて, 半製品在庫が工程間に設定されている。半 製品の在庫品目数は 24 種類で, 各半製品とも 1 日あたり平 均需要量は $32 \sim 111$ で, 1 日の平均需要量の総和は 1600 個で ある。半製品在庫までの供給リードタイムの合計は 5 日で, 1 日の操業能力は 1600 個を目標に生産している。各品目の 生産は, 生産効率を高めるために需要量の多い製品からまと

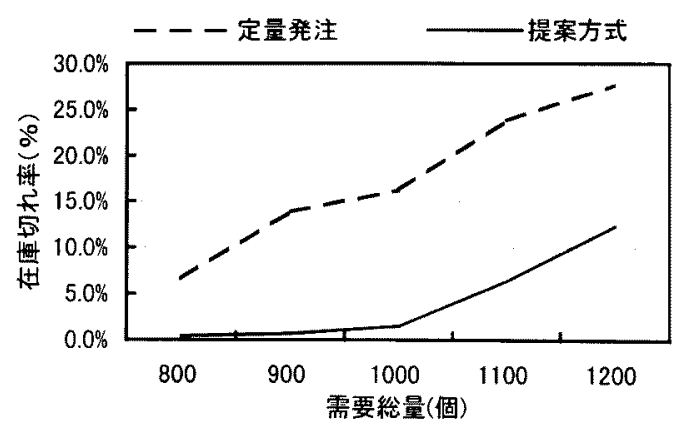

図 11 需要総量変動時の平均在庫切れ率シミュレーション Fig. 11 Simulation Result of Average Out of Stock Ratio in Total Demand Quantity Variation

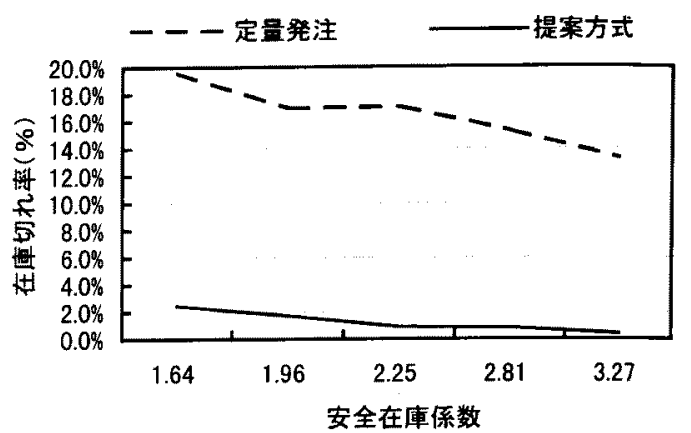

図 8 平均在庫切れ率のシミュレーション結果

Fig. 8 Simulation Result of Average Out of Stock Ratio

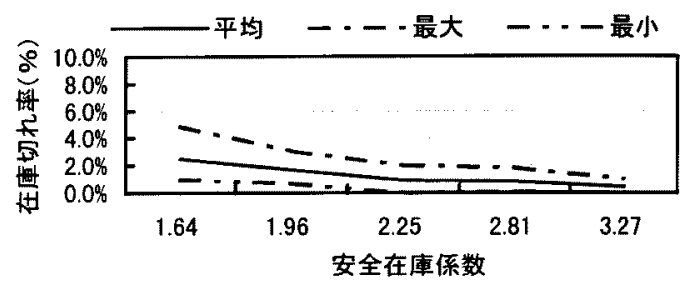

図 9 提案方式の最大・最小在庫切行率

Fig. 9 Maximum and Minimum Out of Stock Ratio In Optimal Ordering Method

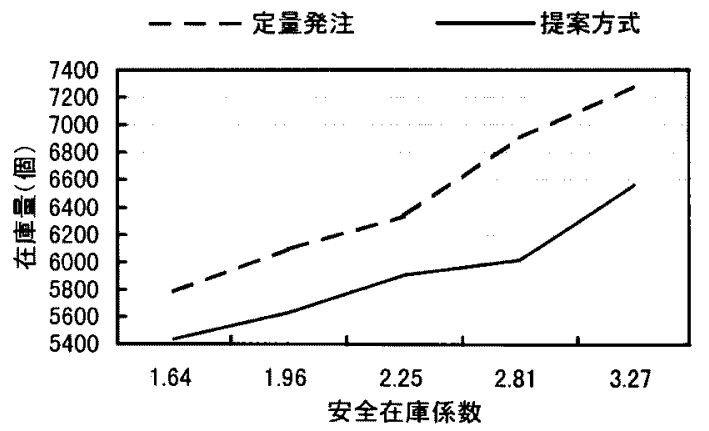

図 10 在庫総量のシミュレーション結果

Fig. 10 Simulation Result of Total Inventory

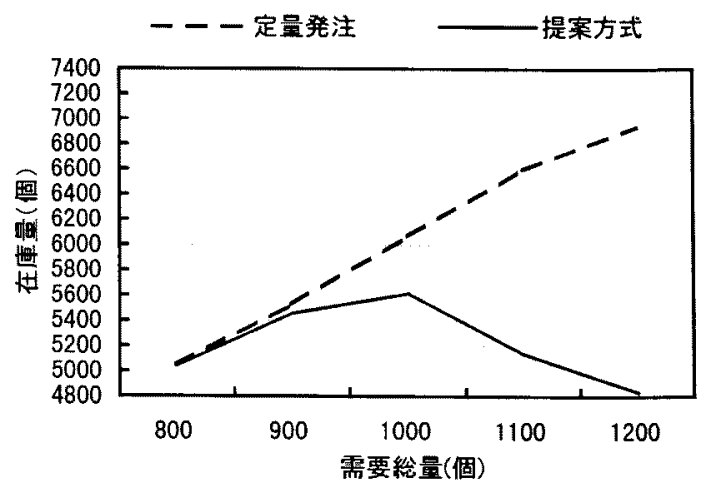

図 12 需要総量変動時の在庫総量のシミュレーション Fig. 12 Simulation Result of Total Inventory in Total Demand Quantity Variation 
めて生産し 1 カ月で 24 製品を一巡していた。そのため, 月 の途中で在庫切れが発生すると, 生産計画に割り込みを入れ て緊急に生産し，1〜2 日の納期遅れで対応していた。その結 果, 操業能力は生産計画に対して+25\%を超えることがたび たびあった。また, 半製品の在庫量は月あたり販売数量の 0.9 カ月分を保有していた。

在庫切れによる緊急生産と納期遅れを無くしたいという 要望を受けて, . 最適化在庫補充方式を試行した。1日の操業 能力は平均需要量の 1.1 倍の 1760 個に設定し, 上限余裕在 庫率を 2.0 に設定し，各半製品の補充要求量を $400 \sim 530$ に 設定して 1 日に $3 \sim 4$ 回の段取り替えを行った。その結果, 操 業能力を超えた補充要求と在庫切れは無くなり, 合わせて, 半製品の在庫量は, 緊急生産分が取り除かれたため, 月あた り販売数量の 0.65 カ月分となり $28 \%$ を削減し, 本提案方式 の効果を確認した。

7. おわりに

本論文では，操業能力に制約がある多品目在庫補充におい $\tau$, 複数品目が同時に補充要求し, 操業能力を超えた場合に 優先的に生産したい補充品目を決め, または, 操業能力に余 力が発生した場合に, 多品目の中から先行して生産したい補 充品目を決める方式を提案した。各品目の供給リードタイム 期間内の需要量に対する有効在庫量の比を余裕在庫率と定 義し, 余裕在庫率が小さい順に各品目を並べ替え, 操業能力 と上限余裕在庫率の範囲内の品目を補充要求する。各品目を 余裕在庫率で並べ替えて優先補充することで在庫切れ率が 最小化し, かつ, 上限余裕在庫率の範囲内で先行補充するこ とで安全在庫量を確保しつつ在庫総量の增加を抑止でき，そ の有用性をシミュレーションにより示すことができた。また， アルミ製㥶枠メーカへの適用を通して, 在庫切れ率の低減と 在庫量の削減, 平準化生産に効果があったことを示した。

なお，本論文では，個別品目と多品目の違いを明らかにす るため在庫補充方式に限定して考察したが, 害用上は, 供給 工程側のスケジューリング方式と組み合わせて検討すが必 要である。しかし，現在のところ，どのような組み合わせ方 が良いかは経験に頼って決定されている。また, 余裕在庫率 の決定の重要な要因に補充要求量があるが, 同様に経験的な 試行錯誤で決定されている。提案方式の合理的，自動的な動 作条件を設計するためには，このような経験的な設計項目に ついての定量的な検討が必要である。

(平成 11 年 9 月 27 日受付, 平成 12 年 4 月 21 日再受付)

\section{参考文献}

(1) J. F. Magee: "Production Planning and Inventory Control", McGrawHill, Chapt. V, 1958.

(2) T. Tabe, R. Muramatsu and Y. Tanaka: "Analysis of Production Ordering Quantities and Inventory Variations in a Multi-stage Production Ordering System", Int. J. of Production Research, Vol. 18. No. 2, pp. 245-257, 1980.

(3) A. G. Lagodimos and E. J. AndeRmon: "Optimal Positioning of Safety Stocks in MRP”, Int. J. of Production Research, Vol. 31, No. 8, pp. 1797-1813, 1993.
(4) W. H. Hausman and N. K. Erkip: "Multi-echelon vs. Single-echelon Inventory Control Policies for Low-demand Items", Management Science, Vol. 40, No. 5, pp. 597-602, 1994.

(5) J. S. Song: "The Effect of Leadtime Uncertainty in a Simple Stochastic Inventory Model", Management Science, Vol. 40, No. 5, pp. 603-613, 1994.

(6) 光国光七郎, “在庫削减と注文即応の両立を目指した生産管理手 法”, 生産スケジューリングシンポジウム’96 講演集, 日本経営 工学会, pp. 235-240, 1996.

(7) K. Mitsukuni, I. Tsushima and N. Komoda: "Optimal Ordering Method for Coupling Point Production Control System”, in Proc. of IEEE Int. Symp. on Industrial Electronics '98, Vol. 2, pp. 568-572, 1998

(8) Little, J. D. C.: "A Proof of the Queuing Formula: $\mathrm{L}=1 \mathrm{~W}$.", Operation Research, Vol. 9, pp. 383-387 (1961).

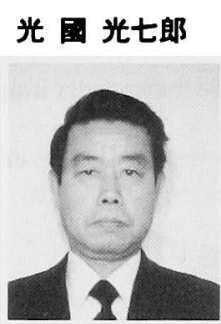

（正 員）1950 年 3 月 22 日生まれ。 85 年 3 月創 価大学経済学部卒業。6 8 年 4 月日立システムエ ンジニアリング侏入社。69 年 2 月侏日立製作所 転属。現在, 同社ビジネスソリューション開発本 部主任技師。2000 年 3 月大阪大学大学院工学研 究科情報システム工学専攻博士後期課程修了。 博士(工学)。生産情報システムの研究に従事。 情報処理学会, 計測自動制御学会, IEEE などの会 員。

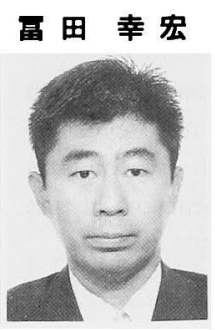

（非会員）1967 年 6 月 25 日生まれ。 90 年 3 月早 稲田大学理工学部工業経営学科卒業。9 3 年 3 月 同大学院理工学研究科機械工学専攻修士課程修 了。同年(株) 日立製作所入社。現在, 同社ビジネ スソリューション開発本部技師。製造企業に対 する生産管理システムの分析・設計業務に従事。

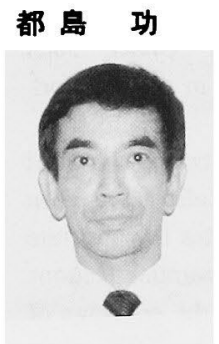

（正 員）1945 年 6 月 6 日生まれ。6 8 年名古屋 工業大学計測工学科卒業。70 年大阪大学基礎工 学研究科制御工学専攻修士課程修了。同年 (株) 日立製作所入社。同社中央研究所, システム開発 研究所, システム開発本部を経て, 98 年 4 月より 四日市大学環境情報学部教授。工学博士。一貫 して物流システムの計画・管理・制御技法に関 する研究に従事。計測自動制御学会, IEEE など の会員。
蔍田潞久

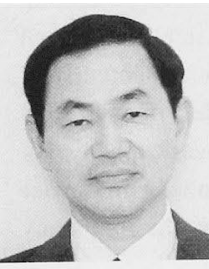

（正 員）1950 年 2 月 27 日生まれ。 74 年 3 月大 阪大学大学院工学研究科電気工学専攻修士課程 修了。同年(株) 日立製作所入社。システム開発 研究所に所属。81 82 年 UCLA 留学。91 年 4 月 大阪大学工学部情報システム工学科助教授。現 在, 同大学院工学研究科情報システム工学専攻 教授。工学博士。情報システム工学, 知識情報 処理などに関する研究に従事。計測自動制御学 会 86 年度論文賞, 同学会 87 年度技術賞, 電気 学会 98 年度論文賞受賞。IEEE などの会員。

註都島は, 日立製作所在職時に本研究の共同研究者として参加した。 現在は, 四日市大学に所属している。 